\title{
PENERAPAN ANALISIS TRANSAKSIONAL DALAM TERAPI PERKAWINAN BERDASARKAN PENGALAMAN PRAKTEK
}

\author{
Ahmad Gimmy Prathama Siswadi \\ Fakultas Psikologi Universitas Padjadjaran Bandung \\ Email: ahmad_gimmy@yahoo.com
}

\begin{abstract}
Transactional analysis concept is firstly introduced by Eric Berne at 60's. the books "Games People Play" and "Transactional Analysis in Psychotherapy" written by Berne, and also "I'm OK You're OK" written by Thomas Harris explain those concept obviously. Transactional analysis concept could be applied in marriage therapy. Recognition about spouse's ego state could be the early step to fix up the marriage relationship. Husband or wife could figure out the transactional situation in their relationship, whether they would like to make use of their ego state as parent, adult, or child. The relation between therapist and client, so does relation between spouses, are also the significant factor in marriage therapy. Hopefully, in-depth understanding about relationship concept in transactional analysis perspective would increase both the therapy effectiveness and the position of the clients \& therapist. Example of this concept in a marriage therapy is intended to increase the understanding about how to operationalize this concept into the therapy.
\end{abstract}

\section{Keywords: transactional analysis, parent-adult-child ego state, existential position}

Ketika berupaya merealisasikan perannya dalam lingkungan sosial, manusia menggunakan pola yang berbeda-beda. Berne (1961) mengungkapkan bahwa individu menampilkan diri dalam situasi interpersonal dengan kecenderungan ke salah satu dari tiga pola ini, yaitu diri sebagai orang tua (parent), orang dewasa (adult), dan kanak-kanak (child). Ada yang pernah menyebut anggota DPR sebagai seperti Taman Kanak-Kanak karena keinginan sesaatnya yang minta segera dipenuhi. Ketika anak-anak berperilaku layaknya orang yang lebih tua dari usianya (cerewet dan penuh tuntutan misalnya), orang-orang pun menyebutnya sebagai 'seperti nenek'. Hal tersebut merupakan cerminan bahwa manusia cenderung berperan sebagai suatu entitas yang --disadari atau tidak-- ia tampilkan dalam situasi sosial dan menjadi cara yang akhirnya terpola dengan sendirinya ketika ia berhadapan dengan situasi sosial. Lain situasinya memang bisa lain pula tampilan perannya, namun paling tidak secara mendasar tampilan peran tersebut merupakan sesuatu yang khas/unik, yang tidak dimiliki oleh orang lain. Hal itu akan membentuk konsep diri dan mendasari bagaimana ia akan memandang dunianya.

Tentunya pola tersebut juga dapat muncul ketika ia berada dalam situasi relasi suami-isteri. Konsep diri dan cara memandang dunia yang tertampilkan dalam peran orang tua, orang dewasa, dan kanakkanak akan mewarnai corak relasi yang terbangun, sehingga secara terintegrasi, resultan dari pola-pola tersebut akan membentuk kondisi bersama yang nantinya akan dapat dinilai bahagia. Sebaliknya bisa saja relasi mereka penuh konflik dan persaingan, sehingga mempengaruhi kesejahteraan rumah tangga dan keluarga yang mestinya dibina ke arah situasi dan kondisi yang konstruktif.

Tulisan ini akan memuat contoh tentang bagaimana ketiga peran yang ada di dalam diri ber'transaksi' melalui relasi diadic suami-isteri dan dinamika masalah yang mungkin muncul di antara keduanya. Tulisan ini juga diharapkan dapat memunculkan rencana tindakan yang terarah dan konstruktif. Selanjutnya, masalah yang 
muncul dari pilihan peran masing-masing dalam relasi suami-isteri akan dapat diarahkan pada pilihan peran yang lebih baik dan lebih maslahat bagi kebaikan rumah tangga itu sendiri. Ternyata, perubahan pola peran bukan sesuatu yang mudah, perlu banyak pengorbanan yang berupa perubahan cara pandang dan bahkan kesediaan untuk menunda desakan eksistensi diri agar dapat 'lebur' ke dalam relasi yang lebih baik, komplementer, dan seimbang. Tanpa kesediaan tersebut, keselarasan relasi suami isteri yang harmonis akan lebih sulit terwujud.

\section{ANALISIS TRANSAKSIONAL DARI BERNE}

Relasi antar manusia dapat digambarkan dalam bentuk komunikasi antara pilihan-pilihan peran yang mungkin dilakukan manusia tersebut. Peran orang tua, orang dewasa dan kanak-kanak dipilih, dan ditanggapi oleh 'pasangan' dengan corak pilihan peran yang tertentu pula, sehingga membentuk suatu relasi yang terintegrasi dan unik. Setiap peran sebetulnya memiliki valensi positif dan negatifnya sendirisendiri. Pilihan peran sebagai orang tua, tidak selamanya buruk. Begitu pula pilihan sebagai kanak-kanak. Orang yang sesekali 'bermain' seperti kanak-kanak, dalam situasi yang tepat dan kondisi yang mendukung, bisa menjadi orang sehat yang bahagia dan sejahtera. Peran sebagai orang tua yang melindungi dan mendukung, juga dapat menjadi pilihan yang tepat dalam situasi yang memang mendukung untuk itu. Namun, terkait dengan ego yang dimiliki seseorang, pilihan peran orang tua bisa bergerak ke arah kutub otoriter, dan pilihan sebagai kanak-kanak dapat bergerak ke arah anak bebas, yang mau 'seenaknya' sendiri, sehingga butuh penyeimbang, yakni kemampuan untuk berperan sebagai orang dewasa yang rasional, empirik/faktual, dan bertanggung jawab.

Berne (1961) menyebut pola transaksi yang sudah terbentuk pada individu itu sebagai 'ego state' (status ego). Status Ego terjadi silih berganti sebagai hasil transaksi manusia dengan lingkungan, melalui skenario kehidupan yang terjadi sepanjang hidup. Pemahaman akan peran yang dipelajari secara sadar maupun tidak, pada akhirnya membentuk manusia sehingga ia akan memilih pola status ego tertentu ketika berada dalam situasi relasi. Evaluasi yang terus menerus akan kehidupan yang terjadi dan interaksi dengan berbagai pribadi yang signifikan akan menghasilkan suatu 'existential positions' tertentu dari individu. Manusia yang dibesarkan dalam kehangatan dan saling percaya akan menumbuhkan posisi eksistensial 'I'm OK, You're OK' dalam kehidupannya. Ia dapat melihat sisi baik dari orang-orang yang signifikan dan hidup konstruktif bersama-sama dengan orang lain membentuk transaksi yang komplementer antara satu dengan yang lainnya. Manusia yang hidup dengan ancaman dan penuh tekanan akan melihat lingkungannya sebagai lingkungan yang 'merusak' sehingga muncul posisi eksistensi yang 'I'm $O K$, you're not $O K^{\prime}$.

Akibat lanjutan yang sering muncul adalah menyalahkan orang lain dan bersikap agresif terhadap lingkungan. Sementara itu kehidupan yang membentuk manusia sebagai orang yang tanpa makna, diabaikan, selalu direndahkan dan akhirnya merasa tidak berdaya, akan menempatkan dirinya pada posisi eksistensi 'I'm not OK, You're $O K^{\prime}$. Akibatnya, manusia cenderung menyalahkan diri dan menghukum diri secara tidak proporsional. Sementara itu, kondisi yang serba salah dan mengarah pada keterpurukan akan membentuk posisi eksistensi 'I'm not $O K$, You're not $O K$ ', tidak ada yang 'OK' baik diri maupun orang lain, semuanya buruk! Inilah kondisi terburuk yang akan membawa relasi yang terjadi mengarah pada keputusasaan, apatis, tanpa arah dan tiada usaha untuk berubah. Kondisi-kondisi ini tampaknya bukan merupakan hal yang statis.

Dalam berbagai contoh kasus, Solomon (2003) memberikan contoh tentang degradasi yang mungkin terjadi sebagai dinamika posisi eksistensial yang dipilih oleh seseorang dalam penempatan perannya di lingkungan sosial. Seseorang yang tadinya cantik, percaya diri, sangat yakin dengan masa depannya, karena pengalaman hidup yang ternyata pahit dan membuat 
dirinya tidak pernah merasa cukup baik (karena prestasi dan kecantikan yang dimiliki selalu harus lebih dan lebih lagi dari yang ia capai), akhirnya tenggelam dalam keputusasaan dan menyalahkan diri sendiri. Pengalaman hidup tidak memberinya hal yang terbaik, sehingga ia larut dalam situasi putus asa, ketika usia dan kesempatannya sebetulnya masih punya peluang untuk berubah.

Dengan demikian, pola relasi manusia dengan orang-orang yang signifikan seperti orang tua, anak, dan pasangan, dapat mengarah pada dinamika posisi eksistensi yang sebenarnya tidak selalu statis. Dinamikanya dapat terjadi karena pemilihan ego state masing-masing dan hasilnya bagi relasi tersebut secara interaktif. Kondisi yang terus menerus dapat memberikan simpulan-simpulan atau evaluasi tertentu yang akhirnya sampai pada suatu pola relasi antar ego yang komplemen atau bersilangan (cross). Ketika persilangan antar kutub negatif terjadi, penurunan kualitas relasi dan posisi eksistensi akan menurun sampai tingkat yang paling tidak konstruktif, dan dapat berujung pada hancurnya integrasi relasi yang tadinya terbina baik.

\section{METODE : STUDI KASUS}

Meski sering dianggap bukan sepenuhnya metode riset, studi kasus lebih menitikberatkan pada penelaahan kasus yang sangat terbatas dengan pembahasan mendalam berdasarkan kerangka berfikir/pendekatan tertentu. Telaahan atau penelitiannya sendiri tidak selalu dicirikan dengan pengambilan data yang rumit dan bervariasi, tapi lebih fokus pada siapa atau apa sebenarnya yang dimaksud kasus yang menjadi bahan analisis dalam studi kita itu (Wilig, 2008). Kasus yang ditelaah bisa saja berupa individu/pasien/klien, pasangan, organisasi, kota, komunitas, sekolah, atau bahkan bangsa atau kerajaan. Bromley (Wilig, 2008) menggambarkan kasus sebagai 'kejadian alami dengan batas-batas ditentukan'. Studi kasus melibatkan eksplorasi yang terarah, mendalam, intensif, dan tajam. Dalam pengembangan ilmu, studi kasus memiliki sejarah panjang dan beragam. Studi kasus telah digunakan dalam berbagai disiplin ilmu seperti sosiologi, politik, sejarah, sosial antropologi, pendidikan dan psikoanalisis. Studi kasus dapat menggunakan metode penelitian kualitatif dan kuantitatif, sehingga studi kasus dapat mengidentifikasi dan menelaah suatu permasalahan secara lebih eksploratif, komprehensif, dan terarah (Wilig, 2008). Studi kasus memfasilitasi pemunculan suatu teori. Eksplorasi rinci tentang kasus tertentu dapat menghasilkan kesimpulan dan temuan dalam proses sosial atau psikologis, yang pada gilirannya dapat menimbulkan formulasi teoritis dan hipotesis. Studi psikoanalisis Freud merupakan contoh yang jelas tentang hubungan antara studi kasus dan pengembangan teori. Hamel (Wilig, 2008) menyatakan bahwa studi kasus juga dapat digunakan untuk menguji teori yang ada atau untuk mengklarifikasi atau memperpanjang teori-teori seperti itu, misalnya dengan melihat kasus menyimpang atau ekstrim secara mendalam sesuai dengan teori tertentu yang ingin lebih kita fahami.

Dalam artikel ini, metode studi kasus diterapkan untuk mengerti secara lebih mendalam dinamika dan proses terapi yang terjadi pada klien dengan pendekatan transactional analysis dari Berne dan kolega-koleganya. Tahapan dan proses terapi akan dijelaskan terkait dengan pendekatan tersebut, sambil ditelaah bagaimana efek yang terjadi dan faktor pendukung atau pengganggu yang mempengaruhi keberhasilan proses terapi yang tengah berlangsung. Dengan demikian, berdasarkan tahapan-tahapan terapi yang meliputi asesmen, rancangan terapi, proses terapi, dan evaluasi akan dibahas secara mendalam, lalu kemudian disimpulkan secara sistematis. Berdasarkan hal tersebut dapat direkomendasikan apakah yang dapat diimplementasikan sebagai hasil dari telaah kasus ini untuk penelitian lanjutan dan aplikasi pada kasus-kasus yang sejenis.

\section{KASUS : PASANGAN Y DAN X}

Kasus yang akan diketengahkan sebagai subjek telaahan dalam artikel ini adalah kasus pasangan suami isteri $\mathrm{Y}$ dan $\mathrm{X}$ yang ketika datang ke terapis berusia 25 dan 26 tahun. Suami akan menjalani pendidikan 
akhir di perguruan tinggi, sementara isteri dropped out dari suatu lembaga pendidikan tinggi. Mereka memiliki anak usia 6 tahun dan tinggal di rumah milik orang tua suami dengan biaya hidup yang masih ditanggung orang tua suami juga. Dari sisi ekonomi sebetulnya kehidupan mereka tergolong cukup, namun kekurangmampuan dalam mengelola keuangan rumah tangga dan kondisi sulit yang dialami keluarga besar isteri membuat kehidupan ekonomi mereka belum bisa sampai pada kondisi yang mantap dan stabil. Prioritas keuangan yang mestinya dikeluarkan untuk hal yang lebih produktif, bisa dikalahkan dengan keinginan sesaat yang sifatnya konsumtif, sehingga mereka juga menghadapi tagihan kartu kredit yang nilainya cukup signifikan.

Kondisi keuangan yang kurang dikelola dengan baik merupakan pemicu aktual yang membuat pasangan ini sering bertengkar. Kalaupun ada upaya untuk mengelola usaha seperti yang dilakukan isteri, usaha tersebut seringkali gagal dan malah membuat kehidupan ekonomi mereka menjadi makin sulit. Oleh karena itu timbul eskalasi kekerasan, terutama yang dilakukan oleh Y. Mulai dari menyakiti diri sendiri, merusak barang, mengancam, sampai memukul isteri, 'mencengkram' anak, dan bahkan mengurung anak dalam lemari. Mulanya isteri berani mendebat dan meladeni omongan-omongan keras yang diungkapkan suami, namun ketika sudah mulai dengan perusakan barang dan bertindak keras terhadap anak, isteri mencoba mengurangi perlawanannya. Namun ketika secara tidak sengaja $Y$ melempar pisau dan $\mathrm{X}$ merasa hal itu diarahkan pada dia (suami tidak pernah benar-benar memukul isteri, dan tidak menganiaya secara langsung), X mengancam untuk pergi dari rumah dan pulang ke rumah orang tuanya. Hal ini tidak disetujui Y, karena ia memerlukan X untuk memenuhi kebutuhan relasi suami isteri, dan menilai X masih cukup baik dan akrab dengan anaknya.

\section{ASESMEN}

Berdasarkan pola relasi, penelusuran riwayat hidup serta pemeriksaan psikologi yang dilakukan pada kedua pasangan, status ego yang banyak diperankan keduanya adalah status ego kanak-kanak. Keinginan yang mendahului kebutuhan dan pemenuhan kepuasan sesaat lebih mendominasi gaya hidup mereka, sehingga mereka terjebak dalam penggunaan uang yang kurang terencana dan tidak produktif. Dalam pembicaraan dengan terapis, sangat jarang sekali, bahkan dapat dikatakan tidak pernah, mereka menceritakan tentang anak mereka. Pembicaraan lebih terpusat pada kepentingan ego dan eksistensi masingmasing, sehingga pola relasi mereka tampak berada pada posisi eksistensi 'I'm OK You're not $O K^{\prime}$ dengan status ego sebagai child. Kadang terjadi relasi menyilang di mana yang satu berperan sebagai orang tua dan yang lain sebagai anak, namun peran orang tua yang dipilih adalah orang tua yang otoriter, sementara peran kanak-kanak yang dipilih adalah yang bebas-negatif atau pemberontak, sehingga relasi yang komplementer tidak terjadi.

Usaha untuk meletakkan posisi permasalahan keluarga atau rumah tangga secara rasional dan objektif juga menemui kegagalan. Isteri sering merasa bahwa ia perlu 'mengimbangi' apa yang nantinya 'akan' dicapai suami dengan status sarjana. Ia ingin menjadi seorang isteri yang bisa berusaha/mandiri, namun usaha untuk berwiraswasta dan menuntut ilmu di bidang tersebut mengalami kegagalan. Ia tidak ingin menjadi isteri 'biasa' atau ibu rumah tangga saja, karena merasa banyak kebutuhan ekonomi yang tidak dapat dipenuhi suami (karena mereka sebetulnya sama-sama konsumtif). Akan tetapi, karena kemampuan mengelola usaha dan keuangan yang tidak memadai, semua usaha tersebut cenderung gagal.

Kondisi tersebut membuat kemungkinan degradasi dari 'I' $m O K^{\prime}$ ' dari $\mathrm{X}$ ke posisi eksistensi ' $I$ 'm not $O K^{\prime}$ menjadi besar. Sangat sulit bagi X untuk memahami secara objektif bahwa penentuan prioritas rumah tangga sekarang ini mestinya lebih penting dari pada usaha untuk mempertahankan kondisi ' $I$ ' $m O K^{\prime}$ yang tidak realistis dan kurang berdasarkan 'studi kelayakan' yang baik. Akibatnya, sampai 
dengan 2 (dua) sesi terapi yang dilakukan, kondisi keuangan mereka tidak kunjung membaik dan malah perlu support lebih banyak dari pihak keluarga $Y$.

Secara singkat dapat dikatakan bahwa kondisi rumah tangga $\mathrm{Y}$ dan $\mathrm{X}$ berakar pada masalah konflik relasi dan pengelolaan keuangan yang bersumber dari pola status ego kanak-kanak yang merupakan tampilan peran mereka dalam menjalin relasi suami isteri. Dinamika pemilihan peran yang lain tidak pernah sampai pada status ego yang dewasa. Kalaupun dipilih status ego orang tua, kecenderungannya menjadi otoriter melawan kanak-kanak yang pemberontak atau cenderung pemberontak, sehingga posisi eksistensi 'I'm OK, You're not $O K^{\prime}$ yang menurut Harris (1964) diwarnai kemarahan, tampak lebih terbentuk dibandingkan dengan posisi eksistensi yang lain.

\section{RANCANGAN TERAPI}

Status ego yang berada pada taraf kanak-kanak dalam jangka panjang perlu diubah menjadi status ego yang dewasa. Sebagai peralihan atau transisi, status ego orang tua dan kanak-kanak yang kadang muncul perlu diarahkan agar menjadi status ego yang positif, bukan yang negatif. Namun, mengingat adanya kondisi aktual, yakni pengelolaan keuangan dan utang kepada pihak lain yang mendesak, keterampilam dalam mengelola keuangan ini juga perlu diberikan pada mereka. Modal untuk mengatasi hal tersebut sebetulnya cukup, namun kesadaran yang minim akan pentingnya prioritas dan penentuan urgensi serta kepentingan yang konsisten dalam pengelolaan keuangan, membuat kesepakatan-kesepakatan yang telah dibuat bersama dengan terapis menjadi tertunda, dan hanya sedikit mengalami progres.

Rancangan terapi yang diberikan juga menyangkut prioritas lain yang menyangkut pengembangan rumah tangga ini. Artinya, selain mengatasi masalah ekonomi, keluarga perlu fokus pada masalah apa yang perlu menjadi prioritas dan mana yang tidak. Kesepakatan pada akhirnya mengarah pada pembagian peran dalam keluarga yang menyangkut bagaimana agar keluarga ini nantinya secara bertahap mengarah pada 'kemapanan'. Y tampaknya memiliki kesempatan lebih besar untuk 'mapan' terlebih dahulu karena berbagai peluang yang dimilikinya saat ini (sebagai calon sarjana, mampu secara intelektual dan mendapat dukungan ekonomi untuk itu).

Prioritas kedua adalah kesehatan mental anak. Anak perlu mendapat bimbingan yang konsisten dari ibu dan ayah, dan $\mathrm{X}$ memegang peranan penting di sini, karena X cukup dekat sebenarnya dengan anak, dan mampu mengasuh anak secara cukup baik.

\section{PROSES TERAPI}

Proses terapi sebenarnya sudah sampai pada kesepakatan tentang rencana-rencana yang telah dibicarakan dalam rancangan terapi. Namun, di tengah pertemuanpertemuan yang baru terjadi 5 kali dalam kurun waktu 6 bulan - termasuk 2 (dua) kali pemeriksaan psikologi (pertemuan jarang dilakukan karena suami sudah mulai masuk dalam kegiatannya sebagai calon sarjana) terdapat peluang bagi isteri untuk mencoba melakukan usaha 'event organizer' yang ternyata gagal dan malah membuat utang mereka membesar kembali. Padahal, eskalasi kekerasan sebenarnya sudah tidak terjadi, dan mereka sudah mulai mencicil hutang yang ada dengan aset yang mereka miliki sebagai pasangan. Ternyata, $\mathrm{X}$ tidak begitu nyaman dengan posisinya saat ini dalam peran yang ia anggap sebagai 'supporting' saja. X merasa 'tidak sabar' dengan kondisi tersebut dan melihat kemungkinan munculnya gap yang besar bila $Y$ nanti sudah menjadi sarjana dan $X$ (dalam istilah $\mathrm{X}$ sendiri) 'bukan apa-apa'. Membesarkan anak dan mensukseskan pendidikan anak ternyata bukan sesuatu yang membuatnya merasa berarti. Meski X tahu bahwa hal itu mulia, namun tampaknya hal tersebut lebih merupakan pendapat yang hanya sampai pada tingkat kognitif yang belum dihayati secara mendalam. Artinya, X perlu digugah untuk lebih sering menampilkan status ego orang tua yang konstruktif, dan berupaya untuk menemukan makna posistif dalam peran/eksistensinya tersebut, dibandingkan child/kanak-kanak 
yang menuntut dan ingin cepat meraih keinginan (misalnya ingin jadi pengusaha, berhasil secara ekonomi secara cepat dan langsung) yang selama ini menjadi karakteristiknya.

\section{EVALUASI}

Jalinan relasi yang terbentuk pada pasangan $\mathrm{Y}$ dan $\mathrm{X}$ tampaknya belum sampai pada jalinan relasi yang komplementer dan konstruktif. Relasi persilangan atau cross memang sudah mulai berkurang, namun dengan timbulnya 'masalah' baru, jalinan relasi yang terbina kembali memburuk, sehingga harus dimodifikasi agar bisa berubah sesuai dengan tujuan terapi yang semula.

Upaya untuk mengarahkan pasangan ini agar dapat mulai melatih status ego orang dewasa sebenarnya sudah dimulai dengan memberikan latihan dan wawasan untuk menetapkan prioritas berdasarkan urgensi dan kepentingan penyelesaian masalah, satu demi satu. Kesadaran bahwa masalah pencapaian karakteristik orang dewasa atau paling tidak orang tua yang moderat dan mendukung perlu dilatih sudah ada. Namun, tingkat pemahamannya masih berbeda antara $\mathrm{Y}$ dan $\mathrm{X}$, sehingga ketika ada pemicu masalah lain, hal tersebut belum cukup kuat untuk bertahan di tengah 'serangan' masalah baru yang muncul.

'Prognosis' untuk kasus ini sebagai pasangan dapat dikatakan negatif, terutama karena support sosial dari keluarga besar masih terbatas pada support yang sepihak dan kurang berimbang. Namun untuk suami (Y) sebagai pribadi, terapi ini tampak mulai memberikan manfaat. Kesediaan untuk memanfaatkan kemampuannya dalam berfikir rasional dan objektif, meski belum sepenuhnya 'rela' dan optimal, sudah membuatnya mengurangi dengan cukup drastis kecenderungan kekerasan yang dilakukan. Ia berusaha 'menomorduakan' keinginan sesaat yang konsumtif, dan 'gangguan' baru yang dialami bersama X, untuk tetap bertahan pada prioritas keluarga kecil yang telah ditetapkan semula dalam sesi terapi awal. Namun, hal ini tampaknya tidak mudah, karena komitmen yang belum 'bulat' antara pihak $\mathrm{Y}$ dengan $\mathrm{X}$ sebagai pasangan suami isteri.

\section{RENCANATERAPI SELANJUTNYA}

Rencana terapi selanjutnya masih akan dilakukan dengan pemantapan relasi transaksional yang komplementer dan konstruktif di antara pasangan ini. Anak, secara khusus juga sudah ditangani psikolog anak, dan tampaknya cukup dapat mengikuti pendidikan di sekolah dengan baik dan optimal. Namun terapi yang dilakukan tampaknya perlu diarahkan agar didapatkan acceptance dan commitment dari kedua belah pihak yakni Y dan X, secara konsisten dan berkelanjutan. Peningkatan dalam memahami dan menerapkan pola komunikasi orang dewasa, misalnya dengan kata-kata yang dekat dengan aplikasi sebagai orang tua yang supportif perlu dilatihkan lebih banyak lagi. Efek dari terapi memang baru terlihat pada $\mathrm{Y}$, namun meski disadari bahwa waktunya tidak akan singkat, $\mathrm{X}$ juga sebenarnya masih memiliki peluang untuk mendapatkan progres terapi secara lebih positif. Monitoring perlu dilakukan lebih intens, sehingga kalau terjadi situasi yang mendadak dan berpotensi mengubah arah terapi, hal tersebut dapat diantisipasi secara lebih baik dan terarah.

\section{SIMPULAN}

Meski belum mendapatkan hasil yang maksimal dalam penerapan analisis transaksional dalam psikoterapi ini, namun bagi diri Y hal tersebut cukup memberikan dampak yang signifikan. Cara pandang yang lebih dewasa dan kesediaan yang tinggi untuk menerapkan status ego sebagai orang dewasa memang memerlukan langkah yang bertahap. Kemampuan mengolah data dan memfokuskan diri pada situasi yang 'real' merupakan salah satu pendukung perubahan pada diri Y. Ia mampu mengambil pelajaran dari pengalaman-pengalamannya dan mencoba menjadikan pengalaman tersebut sebagai sarana untuk memperbaiki kondisinya. Fokus pada sasaran jangka pendek yang harus dicapai merupakan hal penting. Meski mungkin hal ini menjadi lebih mudah karena 'in-line' dengan posisi eksistensi 'I'm $O K$ ' dari Y, kesediaan untuk terus melatih dan mengubah diri secara konsisten, perlu dicapai dengan usaha yang 
cukup.

Pada diri $\mathrm{X}$, posisi ' $I$ 'm $O K^{\prime}$ juga sebetulnya perlu dipertahankan, me-'restruktur' kognisi bahwa pekerjaan sebagai ibu saat ini lebih diperlukan daripada pencapaian jati-dirinya sebagai pengusaha, merupakan salah satu upaya untuk itu. Namun ternyata itu tidak mudah, karena kesediaan untuk menunda keinginan sesaat sebagai wirausahawan, ternyata sangat sulit dilakukan. Padahal kesediaan untuk menunda itulah yang mungkin akan mendapatkan penilaian 'You're OK' dari Y sebagai pasangannya, sehingga pada akhirnya-melalui perjalanan panjang dan integrasi berbagai pendekatan terapi seperti Analisis transaksional, CBT (Cognitive Behavioural Therapy), dan juga ACT (Acceptance \& Commitment Therapy), posisi eksistensi 'I'm $O K$, You're $O K$ ' dapat dicapai secara efektif.

\section{REKOMENDASI}

Dengan menelaah dinamika perubahan pola komunikasi dan transaksi yang dilakukan dalam terapi, arah terapi pasangan sebenarnya bisa menuju pada perbaikan yang konstruktif. Asesmen yang rinci dan rencana terapi juga harus dilakukan secara seksama sehingga akan didapat suatu rencana implementasi yang realistis dan antisipatif. Pola relasi perlu diarahkan pada posisi 'I'm $O K$, You're OK'. Mengubah status ego pada pola yang lebih konstruktif seperti Dewasa dengan Dewasa memang penting, namun sesekali mengambil posisi sebagai Orang Tua atau Anak yang positif juga masih memungkinkan, asalkan tidak terjatuh pada posisi Orang Tua dan Anak yang negatif seperti mengatur, mau menang sendiri, dan terlalu banyak menuntut. Keterampilan untuk menampilkan posisi ini juga bagaimanapun membutuhkan waktu dan perlu latihan yang cukup.
Proses terapi juga bisa menjadi ajang edukasi untuk mencapai kompetensi posisi Dewasa yang konstruktif pada relasi transaksional kedua pasangan, sehingga dengan pengetahuan yang cukup tentang posisi peran dan status relasi transaksional di antara keduanya, keyakinan untuk memandang penting pencapaian posisi dewasa, sesuai dengan pendekatan TA, dapat dicapai dan diimplementasikan secara tepat.

\section{DAFTAR PUSTAKA}

Berne, E. (1961). Transactional Analysis in Psychotherapy. New York: Grove Press, Inc.

Berne, E. (1964). Games People Play. New York: Grove Press, Inc.

Harris, T.A. (1967). I'm OK - You're OK. New York : HarperCollins Publishers Inc.

Ledley, D., Marx, B., \& Heimberg, R. (2005), Making Cognitive-Behavior Therapy Work, New York: The Guilford Press.

Solomon, C. (2003). Transactional Analysis Theory: the Basics. Transactional Analysis Journal, 33, 15-22.

Wilig, C. (2008). Introducing Qualitative Research in Psychology: Adventures in Theory and Method, $2^{\text {nd }} \mathrm{ed}$., Berkshire: Open University Press Mc.Graw-Hill Education

Zuckerman, E. (2010). Clinician's Thesaurus, $7^{\text {th }} e d$. ., New York: The Guilford Press. 